\title{
Isolation and Characteristics of Corn-Based Cellulolytic Fungi as Fibrous Feed Bioactivators
}

\author{
M Delfiyana, Yunilas, S Umar, N Ginting, Hasnudi \\ Animal Production Program Study, Faculty of Agriculture, University of North \\ Sumatera, Medan 20155, Indonesia \\ E-mail: yunilas11@gmail.com
}

\begin{abstract}
Microbes live in nature freely in water, air, or soil. One type of microbe is fungi. Fungi are microorganisms that are able to degrade fiber. This study aims to isolate fungi from corn waste and test the degradation ability of the best corn waste fungi fiber as a fibrous feed bioactivator. This research was carried out at the Laboratory of Animal Production, Faculty of Agriculture, Animal Husbandry Study Program, University of North Sumatra, in March 2018 - June 2018. This study used corn waste (corn cobs, corn straw, corn husk, corn flowers and corn roots). Parameters observed were macroscopic morphology (colony size, colony shape, clony color, colony elevation, colony edge), microscopic morphology (form of hyphae, conidial shape, and conidiophoric surface) and the ability to degrade fiber in fungi.

Conclusions from the results of research on corn waste exploration obtained 6 fungi isolates, 4 of which were cellulolytic fungi that were able to degrade fibrous feed, namely two strains of Aspergillus sp., Fusarium sp., And Rizoctonia sp. Isolates which have a potential to degrade fiber are JE isolates (Rizoctonia sp. fungi) with a cellulolytic index of 1,178.
\end{abstract}

\section{Introduction}

In general, fungi / fungi are berspora plants that are non-chlorophyll organisms, so that fungi cannot provide their own food by photosynthesis as in plants with chlorophyll Suriawiria [1].

Low availability of animal feed is influenced by seasons, climatic conditions, and other factors. According to Sudirman and Imran [2] the waste of corn plants has a high crude fiber content of \pm $28 \%$. This results in low digestibility of feed. So that it is done to increase the value of the benefits of corn waste through biological feed processing technology through complete corn feed fermentation. According to Yunilas et al. [3], indigenous microorganisms are microbes originating from their own substrate which have optimal ability to degrade fibrous feed. Through indigenous microbial exploration, multi enzymes will be produced which are very instrumental in the feed processing process.

Fungi are microorganisms that are able to degrade fiber, but not all types of fungi function to degrade fiber (cellulose), so it is suspected that there are cellulolytic fungi in the corn waste. And an enzyme activity test is needed to see the ability of fungi to degrade fiber by calculating the cellulolytic index. In order to obtain the best degradation from the fungi originating from corn which has the potential to degrade fiber.

\section{Materials and Methods}

2.1 Location and Time of Research

The study was conducted at the Faculty of Agriculture Production Laboratory, University of North Sumatra, for 3 months starting from March to June 2018. 
2.2 Research Materials and Tools

The material to be used in this study is a sample of isolate sources (corn waste fungi). General PDA (Potato Dextrose Agar) medium, a selective medium for isolation of fungi in the form of a selective agar medium modified using Czapek Dox Agar (CDA) modification medium, namely: $0.2 \%$ NaNO3; $0.05 \% \mathrm{KCL} ; 0.05 \% \mathrm{MgSO} 4.7 \mathrm{H} 2 \mathrm{O} ; 0.001 \% \mathrm{FeSO} 4.7 \mathrm{H} 2 \mathrm{O} ; 0.05 \% \mathrm{KH} 2 \mathrm{PO} 4 ; 0.04 \%$ yeast extract; $2 \%$ agar and 1\% (each CMC, xylan, lignin), chlorophenicol Yunilas [4]. To test the degradation of fiber using modified Carboxy Methyl Cellulosa (CMC) medium, namely: $0.5 \mathrm{~g}$ of peptone, $0.5 \mathrm{~g}$ of yeast agar, $1 \mathrm{~g}$ of K2HPO4, $0.02 \mathrm{~g}$ of MgSO47H2O, $1 \mathrm{~g}$ of $\mathrm{Na} 2 \mathrm{CO} 3,20 \mathrm{~g}$ of agar and $0.5 \mathrm{gr} \mathrm{CMC}$ Yunilas et al. [3]. The tools used in this research were incubator, autoclave, microscope, erlenmeyer, petri disk, test tube, tube rack, pipette, micro pipette, stirer, vortex, bunsen, object glass, cover glass, measuring cup, beaker glass, thermometer, $\mathrm{pH}$ meters, hot plates, digital scales, ovens, calipers, digital cameras.

\subsection{Research Methods}

The research method used is an exploratory method which begins with the creation of indigenous microorganism sources (MOI) adopting the making of local microorganisms (MOL). Isolation using the streak plate method, and the ability to degrade the fiber by measuring the clear zone based on qualitative Coughlan [5].

\subsection{Research Implementation}

Isolation of microorganisms

Corn waste (cob, straw, rind, flowers and roots) as a source of isolates was taken as much as 5 grams and then dissolved in $45 \mathrm{ml}$ of sterile distilled water which was added with $0.85 \%$ physiological $\mathrm{NaCl}$, then diluted series. The results of the dilution series were taken $1 \mathrm{ml}$ then inoculated into the Czapek Dox Agar (CDA) medium. Petri dishes that have been poured on the media to be selective are then isolated using a scratch plate method. The media that has been inoculated is stored in a sterilized box for 72 hours at a temperature of 27 - 290C for observation of growing microbes. The growing colonies observed morphology include the size, shape, color, elevation, and edge of the colony.

Purification of microorganism cultures

The isolates that have grown are then purified (purified) and transferred to the new PDA growth media (Potato Dextrose Agar) according to the characteristics of each colony. Colony culture grows until a single (pure) colony is obtained and allows for the next stage of the process.

Enzyme Activity Test (Ability to Degrade Fiber) qualitatively

Testing enzyme activity to determine its ability to degrade fiber (cellulose) qualitatively Coughlan [5]. Selection was carried out based on the highest (clear zone) ratio to the diameter of the colonies planted by Kleupfel [6].

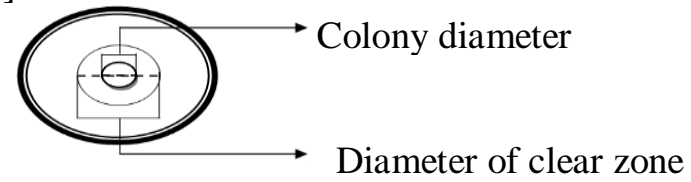

Gambar 1. Clear zone

Ratio of Clear Zone / Cellulolytic Index = Diameter of the Clear-Diameter Zone of the colony Colony Diameter

Parameters observed

The observed research parameters included: Characteristics of fungi in corn waste using morphological observations of fungi. Characteristics of fungi include macroscopic morphological testing (size, shape, color, elevation, and edge of the colony) and microscopically (form of hyphae, conidial shape, and conidiophoric surface). Calculate fungal growth during the 72 hour incubation period. Test of ability to degrade fiber in fungi obtained by Lay [7] and Capuccino and Sherman [8], as well as systematically from fungi obtained.

Data analysis

The research data is presented descriptively in the form of tables or images of Steel and Torrie [9]. 


\section{Results and discussion}

\subsection{Isolation of Fungi from Corn Waste}

In this study, the isolation method of cellulolytic fungi based on corn waste was carried out using a scratch plate method. Corn waste which was successfully isolated came from the plantation of the residents of Jalan Abdul Hakim in the Medan Selayang field in Medan.

The isolates that were isolated were able to grow on selective medium modified by Yunilas et al. [3] with the addition of Carboxy Methyl Cellulosa / CMC, xylan, and tanic acid substrates. After incubation for 72 hours, the fungus colonies were observed for morphology. Then it is purified by cutting a little so that the needle is then transferred to the common PDA medium.

In this study found 6 isolates that grew on selective medium which were thought to be cellulolytic fungi. All isolates obtained were observed macroscopic isolate characteristics including, size, shape, color, elevation, and edge of the colony and observations presented in Table 1.

Table 1. Characteristics of isolates macroscopically

\begin{tabular}{lccccc}
\hline \multirow{2}{*}{ ISOLATE } & \multicolumn{5}{c}{ CHARACTERISTIC } \\
\cline { 2 - 5 } & Size & Form & Colour & Elevtion & Edge \\
\hline JA & Small & Circular & White & Flat & Whole \\
JB & Big & Fibrous & White, middle of moss & Like a & Waves \\
& & green & button & \\
JC & Medium & Irregular & Milky white & Arises & Whole \\
JD & Small & Fibrous & $\begin{array}{c}\text { Moss green, middle } \\
\text { yellowish white }\end{array}$ & $\begin{array}{c}\text { Like a } \\
\text { button }\end{array}$ & Waves \\
& & & White & Flat & Whole \\
JE & Medium & Fibrous & White & Convex & Whole \\
JF & Medium & Fibrous & & & \\
\hline
\end{tabular}

All isolates obtained were measured for the growth of fungi colonies at 72 hours incubation period presented in Figure 2.

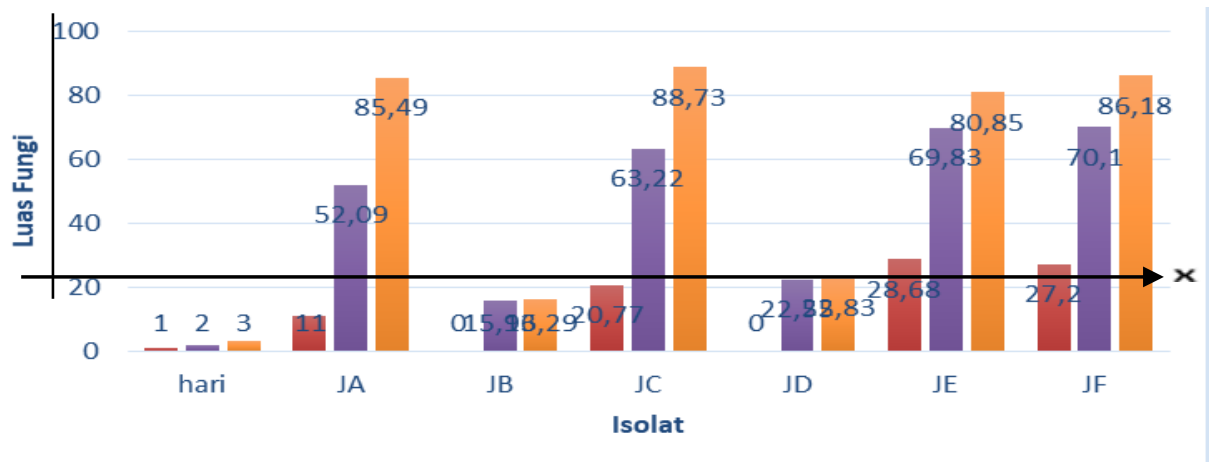

Gambar 2. Grow Chart Fungi

Based on the results and observations showed that the fungi from corn waste experienced growth marked by the diameter of the mushroom colonies getting bigger and bigger. The largest diameter of fungi colonies in the third day of incubation period was JC of $88.73 \mathrm{~mm}$, and the smallest diameter of the colony was JB of $16.29 \mathrm{~mm}$.

\subsection{Measurement of Fungi's Qualitative Activities}

The measurement of clear cellulolytic fungi zones was carried out by testing the enzyme activity to determine its ability to degrade fiber (cellulose). The results showed that each of the six cellulolytic fungi isolates had the ability to degrade different fibers. This can be seen from the diameter of the clear zone formed on the medium containing the modified CMC substrate. The formation of clear zones in each isolate showed that the fungus isolates were able to produce cellulase enzymes. This is consistent with Yunilas et al. [3], which states that the clear zones formed around isolate colonies indicate that the isolates succeeded in hydrolyzing cellulose contained in the media. The presence of 
fungal extracellulose enzymes causes cellulose to be hydrolyzed peptides and simple monomers. In the process of hydrolysis, glucose is perfectly produced.

In this study found as many as 6 cellulolytic fungus isolates. The observations of the clear zones formed are presented in Figure 3.

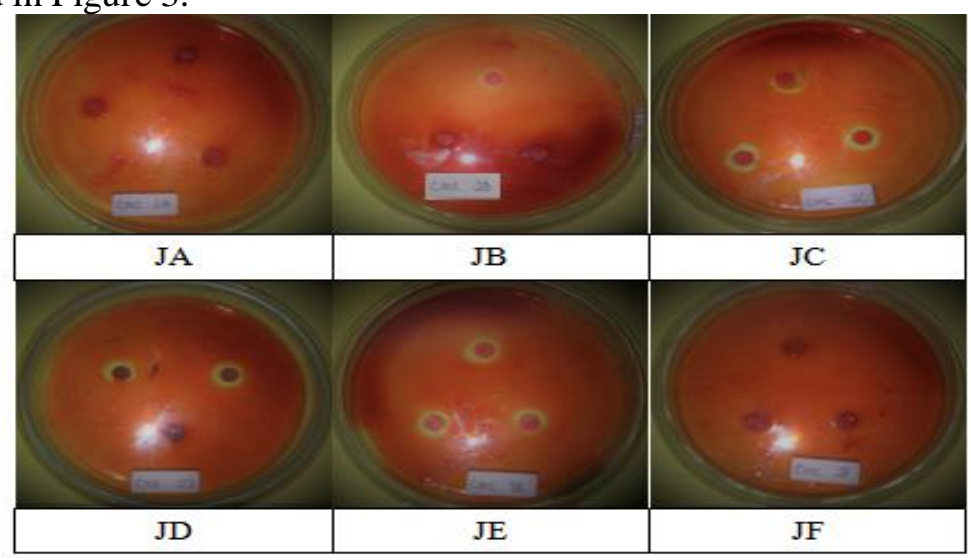

Figure 3. Clear zone of cellulolytic fungi

To see the clear zone to make it look clearer, it is done with a qualitative test by pouring $5 \mathrm{ml}$ of $1 \%$ congo red reagent on the surface of the medium for 24 hours. After that, the excess red congo red dye is rinsed with $1 \% \mathrm{NaCl}$ solution as a washing. Washing will make the clear zone which is inundated by congo red dye resulting from cellulase hydrolysis will become clearer. Khokhar et al. [10] The results of the measurement of clear zones in each isolate are presented in Table 2.

Table 2. Clear zones of isolation of cellulose integration from corn waste

\begin{tabular}{cccc}
\hline Isolate & Clear Zone & Colony & Cellulolytic Index $(\mathrm{mm})$ \\
Fungi & Diameter $(\mathrm{mm})$ & Diameter $(\mathrm{mm})$ & \\
\hline JA & 0 & 0 & 0 \\
JB & 8.37 & 5.00 & 0.674 \\
JC & 9.87 & 5.00 & 0.975 \\
JD & 9.78 & 5.00 & 0.956 \\
JE & 10.89 & 5.00 & 1.178 \\
JF & 0 & 0 & 0 \\
\hline
\end{tabular}

The results showed that of the six isolates, two of them did not have the ability to degrade fiber with no clear zone forming on the media. Of the four isolates that formed a clear zone and the highest cellulolytic index was JE isolate with a cellulolytic index of $1,178 \mathrm{~mm}$. Whereas JA and JF isolates did not form clear zones. Cellulolytic fungi isolates of JE were potential fiber degrading isolates compared to other isolates. According to Yunilas et al. [3], a potential enzyme producer is seen from the highest hydrolysis index compared to others. Ochoa-Solano and Olmos-Soto [11], states that isolates that produce a clear zone diameter twice the diameter of a colony are potential enzyme production.

\subsection{Identification of Fungi}

The identification results of the four fungi showed that the fungi found in the isolation of corn waste were included in 3 genera, namely Fusarium sp., Aspergillus sp., And Rizoctonia sp.

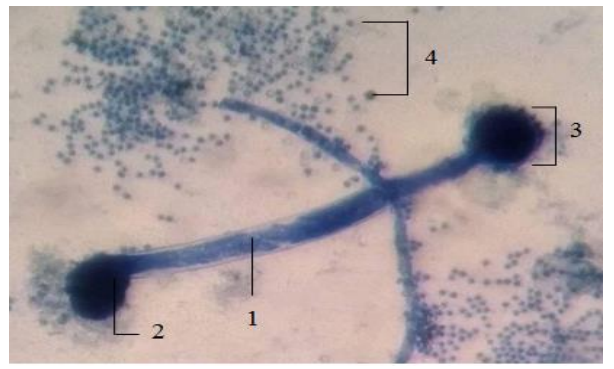


Figure 4. Microscopic Isolates JB (Aspergillus sp.) 1. Conidiophores, 2. Vesicles, 3. Conidial Heads, 4. Konidia / Spores

JB isolates were identified as strains of Aspergillus sp. which has a rounded conidia, a curved condrophic layer, a rounded semi-rounded vesicle and a rounded, concentrated conidial head.

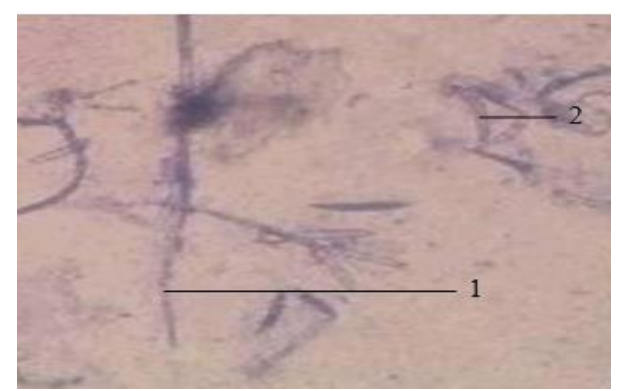

Figure 5. Microscopic Isolates of JC (Fusarium sp.) 1. Conidiophores, 2. Conidia / Spores

JC isolates were identified as Fusarium sp. which has a conidia shaped like a crescent, conidiophores are curved.

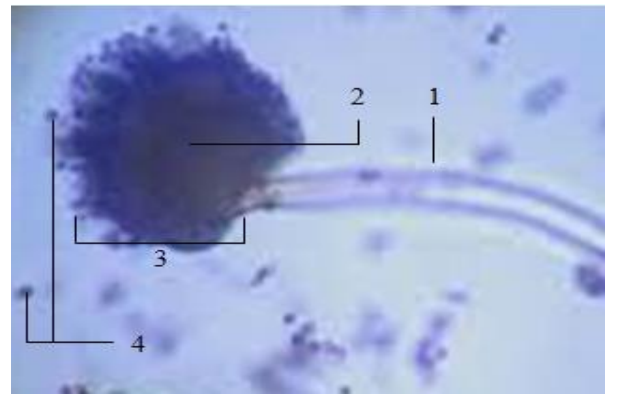

Figure 6. Microscopic JD Isolates (Aspergillus sp.) 1. Conidiophores, 2. Vesicles, 3. Conidial Heads, 4. Konidia / Spores

JD isolates were identified as strains of Aspergillus sp. which has a rounded conidia that is slightly split into several parts, the conidiophores surface is curved, the vesicles are round, the upper conidia are round.

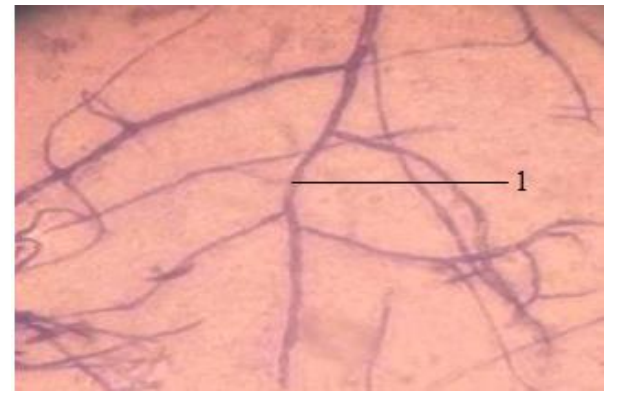

Figure 7. Microscopic JE Isolate (Rizoctonia sp.) 1. Hyphae

JE isolates were identified as strains of Rizoctonia sp. who has branched hyphae and there are insulated grooves.

\section{Conclusion}

The results of research on corn waste exploration obtained 6 fungus isolates that were successfully isolated, 4 of which were cellulolytic fungi that were able to degrade fibrous feed, namely two types of strains of Aspergillus sp., Fusarium sp., And Rizoctonia sp. Based on the best ability to degrade 
fiber by measuring the cellulolytic index, the highest clear zone index in JE fungi isolates (Rizoctonia sp.) Was $1,178 \mathrm{~mm}$ which potentially degraded cellulose.

\section{References}

[1] Suriawiria, U. 2006. Budidaya Jamur Tiram. Kanisius. Yogyakarta.

[2] Sudirman dan Imran, 2007. Kerbau Sumbawa: Sebagai Konverter Sejati Pakan Berserat. Lokakarya Nasional Usaha Ternak Kerbau Mendukung Program Kecukupan Daging Sapi. Fakultas Peternakan Universitas Mataram. Nusa Tenggara Barat.

[3] Yunilas, L. Warly, Y. Marlida, and I. Riyanto. 2013. Potency of Indigenous Bacteria from Oil Palm Waste in Degrades Lignocellulose as A sources of Inoculum Fermented to High Fibre Feed. Pakistan Journal of Nutrition.

[4] Yunilas. 2016. Aplikasi Bioteknologi Dalam Pengolahan Pakan Komplit Menggunakan Mikroba Indigenous Berbasis Limbah Perkebunan Dan Industri Kelapa Sawit Sebagai Pakan Ternak Ruminansia. Disertasi. Program Pascasarjana. Universitas Andalas. Padang.

[5] Coughlan, M. P. 1985. The Properties Of Fungal And Bacterial Cellulases With Comment On Their Production And Application. Biotechnol Gen Eng Rev 3:39-109.

[6] Kluepfel, D. 1988. Screening of Prokaryotes for Cellulose and Hemicelulloses Degrading Enzymes. Methods Enzymology.

[7] Lay, W. B. 1994. Analisa Mikroba di Laboratorium Edisi I. Raja Grafindo Persada. Jakarta.

[8] Cappucino, J. G., and Sherman, N. 1987. Microbiology: A Laboratory Manual. The Benjamin/ Cummings Publishing Company, Inc. California.

[9] Steel, R. G. D., dan J. H. Torrie. 1995. Prinsip dan Prosedur Statistika. Penerjemah Bambang Sumantri. Gramedia Pustaka. Jakarta.

[10] Khokhar, I., M. S. Haider., S. Mustahq and I. Mukhtar. 2012. Isolation and Screening of Highly Cellulolytic Filamentaous Fungi. J. Applied Sci. Envrion. Manage.

[11] Ochoa-Solano, J. and Olmos-Soto, J. 2006. The functional property of Bacillus for shrimp feeds. Food Microbiology. 